\title{
Analysis on the Pension Problems in Loss-of-Single-Child Family: A Perspective of Public Policy
}

\author{
Qi Liu ${ }^{1} \&$ Yuming Wang ${ }^{1}$ \\ ${ }^{1}$ School of Management, Shanghai University of Engineering Science, China \\ Correspondence: Qi Liu, School of Management, Shanghai University of Engineering Science, Shanghai, China. \\ E-mail: Queenie0503@126.com
}

Received: January 1, 2014 Accepted: January 18, 2014 Online Published: April 14, 2014

doi:10.5430/sass.v1n2p16 URL: http://dx.doi.org/10.5430/sass.v1n2p16

\begin{abstract}
In the family, if the only child unfortunately died, the family is thus called "loss of independence families". In recent years, with the increasing of loss-of-single-child family, society has paid more and more attention to the pension problems. Based on a perspective of public policy, combined with the specific practices of the Chinese central government and some provinces and cities, this paper uses the public policy of the analysis theory of elite theory to analyze the status of the loss-of-single-child family, and give the corresponding countermeasures about pension problem of loss-of-single-child family from three aspects: economic support, life care, and spiritual support.
\end{abstract}

Keyword: Loss-of-single-child family, public policy, pension, countermeasures

\section{Introduction}

Loss-of-single-child family refers to the family in accordance with the national family planning policy, the couples have only one child and no live births, and the family does not want to adopt. The loss-of-single-child people are about 50 years old. According to the results of the sixth national census, the average male life expectancy is 72.38 years old, average life expectancy of population to 77.37 years for women. This also means that the loss-of-single-child family will face lost time of 20 or 30 years. Loss-of-single-child family faces something wrong with older. Regeneration is not easy, so is adopting a child. After the majority of the crowd responded positively to the national family planning policy, it can not be underestimated about having produced a number of large scale loss-of-single-child families, when they gradually approaching retirement age. Retirement has become the most concerned issue of loss-of-single-child people, and the pension problem of loss-of-single-child family need to be paid attention to.

\section{Policy Interpretation}

\subsection{National Policy}

1) Premier Zhu Rongji signed the No. 309 State Council Order in 2001, which issued the "Family Planning Regulations in China", and for 27 times the article states: if only child has accidental disability, death, their parents can not give birth again and adopt children, local governments in China should give the necessary help.

2) National Population and Family Planning Commission and Ministry of Finance in China in 2007 issued special family planning support system (the death of the one-child family disability support system), which decided to carry out the experimental work about the one-child family support system for disabled or died from in 2007, for the couple who don't give birth again or legal adopted child when their children disabled or died, the government will give them more 80 Yuan per month or 100 Yuan per month until they death.

\subsection{Local Policies}

1) The office of aging, Municipal Civil Affairs Bureau, the Municipal Finance Bureau in Wuhan jointly issued Hui Lao Xing Zheng: From August 24 to September 10, 2012, if who have the household registration in Wuhan City, one of the spouses more than 60 years old, they have only child of disability, or death only child, and they are have difficult life, they can declare free to enjoy the services of aged care to the domicile of community (village). 
2) The Population and Family Planning Commission in Shaanxi Province issued "advice of establishing a sound support system of loss-of-single-child family pension ",

and put forward clearly the five aspects of assisting: First, raise assisting standards of the loss-of-single-child family. Second, give one-time grant to the loss-of-single-child family. Third, encourage loss-of-single-child family to give birth again. What's more, improve the preferential in social welfare policy about priority in loss-of-single-child family. At last, actively campaigning cares for the loss-of-single-child family.

3) Family Planning Commission in Beijing and the branch of PICC in Beijing begin to cooperate since in 2012, and the government funded for three years in a row, to give loss-of-single-child people 2,800 Yuan per year, and buy insurance for loss-of-single-child family in order to ensure their sense of security. And the government arranges 3000 volunteers to accompany the loss-of-single-child family.

4) The Shanghai Municipal Government Office forwarded the Population and Family Planning, the Municipal Finance Bureau and the CDPF jointly developed the "Shanghai family planning support system for the implementation of special measures" on August 11, 2008. Based on the state regulations, the assistance standards rise by $50 \%$, that is when the only child have disabled, they parents will get assistance payments 120 Yuan per month. When the only child is died, they parents will get 150 Yuan per month.

5) For the policies about helping the loss-of-single-child family in Sichuan Province including: choosing a lump sum of assist gold more than 1,000 Yuan, but also receive a certain amount of assistance payments on monthly or annual (totaling more than 500 per year), giving long-term aid more than three years by the relevant departments, enjoy the relief fund not less than 300 Yuan each year ,or carrying out technical training at least once a year, and choosing to apply for government-funded pension insurance or medical insurance.

\subsection{Revelation}

In order to protect loss-of-single-child people to have normal lives, the Chinese government has issued a series of policies and measures. We can see that the country use a positive attitude to help the loss-of-single-child family from a strategic height, these initiatives reflect that the government and the social have highly responsible attitude to do pension career, but with the advent of China's aging society, the decrease of family size and children, especially the loss-of-single-child family have a lot of missing features, the existing policy measures can not fundamentally solve the problem.

\section{Analysis}

From the public policy of the analysis theory of elite theory, we can know that public policy is developed and executed by the elite, and public policy reflects the power of elite's values and behavior preferences. The Chinese government began to vigorously promote family planning since the early 1970s; birth control became Chinese basic national policy after 1978. According to article 25 of "Constitution" stipulates: "The state promotes family planning so that adapt to population growth with economic and social development plan." "Marriage Law" also stipulates that spouses have the duty to practice family planning. However, the increasing of the loss-of-single-child family is an inevitable result of the national Family Planning Policy, and the parents who have only a child unable to overcome structural deficiencies. In recent years, with the implementation of the family planning policy, resulting in a growing child families. The one-child family has its own uniqueness. In the family structure mode of "four-two-one", the only child is the only rely on the old man in the family, bear the "sacred mission on pension, under a small". However, due to the one-child family also has a vulnerability and risk, as Professor Mu Guangdong proposed that "the one-child family as a simplified extremely family structure, the inverted Pyramid family structure, means that its essence is a kind of risk family". Although one-child family will not expect that meet specific challenge in the future, indeed at any one time, any one area, a certain proportion of the one-child family would become incomplete families. From a global perspective, the risk of one-child families have a cumulative effect with the family cycle unfolds. But there is no relevant departments or authorities announced that the exact data related to the number of China's current number of child death and loss-of-single-child families, the following is experts statistics and inferred several related date about loss-of-single-child family:

(1) The Ministry of Health issued the "2010 China Health Statistical Yearbook" data; the total number of 15 years old of -30 year old child in China is at least 190 million people, mortality in this age of at least 40 per 100,000 people. By this calculation, the loss-of-single-child families are more than one million, and the annual increase of 76,000 people. 
(2) Demographic experts Yi Fu Yin statistical inference based on census data, China produced a total of 218 million loss-of-single-child families from 1975 to 2010, can be equated to speak China produced a total of 218 million children during this period, he also based on population age mortality and figure out which will be 1,009 million people died before the age of 25 , which means China will produce 10 million loss-of-single-child families in future.

(3) According to the army in a sample of the one-child ratios, Liu Mingfu as National Defense University professor were estimated, there is at least a total number of 190 million people of the15-year-old to 30-year-old child in China, combined with the "2010 China Health Statistics Yearbook" shows the population of this age group is $0.4 \%$ mortality projections, there are more than 10 million child deaths before the age of 25 meaning that 20 million mothers and fathers will become helpless loss-of-single-child elderly in 1975 and 2010.

The above data is now the main ideas about the loss-of-single-child family, they have in common is to show that the loss-of-single-child families are increasing in China and they can continue to expand in a few years. The loss-of-single-child family is not only a simple population problem, but also a serious impact on social problems, it need get enough attention of the government and the society. The loss-of-single-child family compared with other groups in society, but also has significant characteristics:

\subsection{Life Becomes Hopeless}

In the family structure mode of "four-two-one", they bears the heavy responsibility in the family. However, with the loss of only child, the family will lose hope in life. Although in 2001, the government promulgated the "China's population and Family Planning Ordinance" clearly stipulates: the only child accident disability, death, the parents do not bear or adopt another child, the local people's Government shall give necessary assistance. In 2007 the government proposed to give the monthly not less than 80 Yuan or 100 Yuan grants. In 2012 September, the Ministry of Civil Affairs has said, through media reports and survey research, the Ministry of Civil Affairs has been noted to loss-of-single-child family problem, and will study the problem as a whole. According to the existing "Three Nos" old standard for the loss-of-single-child family, the problems are solved. A local government also puts forward the suitable new policy for local. Although our government pay attention to the loss-of-single-child family is on the rise and policy is constantly adjusted and refined, do not have a specific policies to "give the necessary help", for the loss-of-single-child family in hardness, where the necessary help for just a general requirement, in the end by a specific department responsible for what and how to implement and enforce such issues, the law does not specifically mentioned. On the whole country there are still many problems will be solved for the loss-of-singly-child family. After an accident or disease of the child, the loss-of-single-child family loses hope and guarantee of life.

\subsection{Lack of Proper Medical Insurance and Pension Insurance}

National People's Congress Zhao Chao found in the survey, only child disabled family back into poverty due to health care and up to $50 \%$. The current policy of family planning especially assistance policy in this area is very limited.The introduction of the family planning special assistance system in 2007, according to the provisions of the conditions given by the government every month not less than 80 Yuan or 100 Yuan grants, until death. Subsequently, all regions combined with the region's economic situation given different assistance payments. According to this understanding, the loss-of-single-child family support for efforts to give the largest is Shaanxi, and support up to 1000 Yuan per person per month, followed by Shenzhen, 770 Yuan per person per month. Most of the region are assistance payments around 100-300 per month. There are some areas to assistance payments is the implementation of one-time assistant, a one-time grant amount is not high. However, for loss-of-single-child family, they lost the child's maintenance, in addition to assistance on meager pensions and grants, they no other way to face now soaring prices, medical treatment is difficult and expensive, they powerless, then drop in the bucket the assistance payment does not fundamentally solve the problem of loss of independence family pension and medical issues.

\section{Solutions}

The pension issues for the loss-of-single-child family are a new challenge for the traditional family model, and it will be a new social problem. Properly handle the pension problem of the loss-of-single-child family is not only related to the family and personal happiness, but also related to social stability. This paper will analyze the countermeasures on the family pension problem from three aspects: economic support, life care and spiritual support.

\subsection{Economic Supporting}

First, it need to expand financing channels and establish the insurance mechanism of one-child family. Give full play to the country's one-child fee and fine of giving more children, so that purchase commercial insurance for one-child 
families. Based on "Population and Family Planning Regulations", when one child was born, according to "one-child glory certificate", their parents can receive 10 Yuan per month for incentive fees until one child 18 years of age. Some scholars said, according to the average of nine provinces and cities of giving more children's fines, 31 provinces and cities nationwide annual levy fines can be up to 27.9 billion Yuan. The insurance money and used for each child, because every single child families are facing child disabled and the risk of death, but due to family child disability and death are in the minority, so the most suitable insurance way to solve the problem, the potential risk for the future to prepare in advance. When a child was killed when an accident occurs, not only give the family a certain economic compensation for loss-of-single-child family and provide some assistance pension, but also reflect the care of the loss-of-single-child family.

Second, the one-time support of the loss-of-single-child family should be put into a long-term support, and ensure that assistance payments value. Disposable aid can play a temporary comfort for the loss-of-single-child family, but it can not solve the pension problem for them. The issuance of long-term assistance payments need to increase the value, set policy dynamic adjustment mechanism for the loss-of-single-child family, according to residents of the region each year consumer price index to be adjusted so that you can ensure that the basic life for the loss-of-single-child family and the loss-of-single-child family income and the life not less than the local average per capita income and average life level.

\subsection{Life Care}

First, a nursing home open only to the loss-of-single-child should be established. The project should be funded by the government to get that family together, and let these parents in this community care for each other and reach out to others. It is learnt that the members of civil organizations, such as Stars harbor, Heart-to-heart home, warm harbor, are hoping to create their own nursing home. In this way, they can meet and support each other and make them broken hearts get comfort. At the same time, it will help groups and community workers provide help, care and support, and supplies a convenience for centralized services. And it will efficiently solve the problem refusing that loss-of-single-child because of absence of guardian at this stage. At present, whether private or public nursing home, when a elder want to enter a nursing home, a application form signed by a guarantor is necessary. General speaking, the guarantor must be immediate family members. But for the loss-of-single-child, without the signature of the children become the largest "obstacle" to be in a nursing home. And in a nursing home, when loss-of-single-child saw other elders have children to visited them, they will feel grief and be more prone to negative emotions. So setting up a nursing home open only to the loss-of-single-child could solve the problem of "the guarantor single" and the negative emotions.

Second, the loss-of-single-child family will include in low-cost housing, affordable housing category. For most of the loss-of-single-child family lost their only child brought great blow to them and it is a great impact on the security. If the children died of illness, it will lead to the greater economic difficulties. According to statistics, there are more than 600 lost only members in Wuhan "heart-to-heart home" and more than half of those families monthly income are 1200 Yuan, and they are about $20 \%$ of the people rely on subsistence living. According to the local government's policy, meet the low-rent housing policy, according to the low-rent housing policy processing. Meet the affordable housing policy, according to the affordable housing policy processing. I think we can practice ideas about living endowment of "heart-to-heart home" in Wuhan, namely according to the principles of voluntary, part of the crowd by commercial housing policy for just living this kind of economic housing commercial housing crowd, does not need to deal with two cards, only need to purchase the right to use property limited, not after death, inheritance rights, housing to the government to recover, to the government to make separate arrangements . So there is corporate living environment for the loss-of-single-child family and a pleasant living atmosphere, but also create a socialist system in peace and harmony under the new model of retirement.

Third, extensive social mobilization should be carried out to play the roles of non-government organizations, communities, families, and the mass media and family planning associations. And establishing a "labor savings"and opening an "time account "for them. In this count, encouraging the low age and healthy old person serve for loss-of-single-child and elders, in this way to sure these actively elders will enjoy the same level of treatment when they are elderly.

\subsection{Spiritual Support}

First, the government should play its role to set up the mental consultation organization and providing them with psychosocial support and mental stimulation. Yuan Weixia, a member of the consultative committee, after a comprehensive investigation of loss-of-single-child family organizations "heart-to-heart home", found that More than 60 percent of elders can not afford this kind of combat and pressure over the death of their children and suffer 
from various degrees of melancholia in a long time. The pain of losing children was like a sharp and merciless sword piercing parents' soul, and most parents can not move past this grief. They dare not go out to talk with others and unable to adapt to the life. Without the professional's involvementnly by self adjusting, it is difficult to help them out of the shadows of losing their children. Government should establish psychology consultation room and organize clinical psychologist consulting to apply mental counseling and return-visit work for those loss-of-single-child family. In this way, we can concern about them psychological dynamics and appease them.

Second, bringing into full play the role of civil society to help those people actively go out of family engage with people and events. As sadness of losing their children, so shut themselves in the lonely space. For this case, non government organizations and Planned Parenthood and so on should act soon to help the family out of their plights and rebuild connections with the society and the spiritual homestead. For example, alone home and firefly commune in Beijing, "heart-to-heart home" in Wuhan, Sichuan's mother's home and so on. They provide psycho-social support to help loss-of-single-child family out of the woods. Besides, let loss lone through internet and various mediums to hold together for warmth is on efficient way.For example, taking part in various parties, communicating via QQ or Skype and so on. Let them in different groups communicate with each other, mutual support and distract their attention, at the end let heart warm friendship break the boredom, depression and loneliness.

Third, promoting volunteer service. Organize a group of the social each occupation volunteer teams to build up children love society, one-to-one to take care of the old man. Then can apply psychological consultation, chat with them and cook for the elderly to eat, wash clothes with them. We should respect the elderly, care for the elderly, cherish the elderly, to set an example so that the elderly can feel the warmth of the children and help them out the mood of disappointment, arose the confident $\mathrm{s}$ and hope of life.If both sides are willing to, also can form a nominal kinship family again, registering Household register in the form of family, but it can not concern with economic profit, and make efforts to recreate a spiritual family.

\section{Conclusion}

The eighteen Report explicitly states that "The improvement of the social assistance system will perfect the social welfare system, support the development of charity, and make the special care and placement better. With the aging of the population, old-age services should vigorously develop. The social security and service system should guarantee the rights of the disabled." As a disadvantaged community, loss alone deserve care from the society and get help from the government. Looking at the old man, at the same time, we should not forget a group of old man with no children waiting for the policy support and services to help.

\section{References}

Chen Wen. From the system to the initiative: The death of one-child families to assist Mechanism. CPC Fujian Provincial Committee Party School, 2012 s2, 114-120.

Li Hua. One million families the pain of loss of independence. Chinese workers, 2012 December, 28-39.

Li lanyong, Wang Xiuying. Emphasis on child accidental death of the family solace demand. Population and Development, 2008 Sixth, 28-30.

Ministry of Health. (2010). China Health Statistics Yearbook. National Population and Family Planning public opinion Weekly, 2012 No. 42.

Mu Guangzong one-child families are essentially risk families. Population Studies, 2004(1).

Song Qiangling. Loss of independent family pension problems and countermeasures. Peoples' Forum, 2013/02/total No. 394, 126-127.

Wang Nanxi, Li Juan. Grave concern Sichuan earthquake alone lost family. Chinese Mitigation, 2012(11), 193, 38-39.

Wu Shiying, Zhou Jian. Plight of child death. Changchun University of Technology (Social Sciences), 26(3), March 2013, 79-81.

Yi Fuxian. Lost independence"should pay particular attention to the pain. Global Network [EB/OL]. Retrieved from http://opinion.huanqiu.com/1152/2012-05/2716503.html 